\title{
健康危機管理と自然言語処理
}

\author{
奥村 貴史 ${ }^{\dagger}$ 金谷 泰宏㹨
}

災害は被災地住民の健康に多大な影響を及ぼし，その対応に際し保健医療分野に膨 大な文書を生じる。そこで, 災害時の保健医療活動を支援するため, 自然言語処理に よる各種文書の効率的処理が期待されている. 本稿では, 保健医療の観点から, そ うした情報の特性を被災者, 被災者集団, 支援者のそれぞれについて整理したうえ で, 自然言語処理が有効と考えられる諸課題を列挙する。そのうえで, 2011 年に発 生した東日本大震災に扔いて筆者らが関わった日本栄養士会支援活動報告, 石巻圈 合同救護チーム災害カルテ, 医療や公衆衛生系メーリングリスト情報の 3 つの事例 を紹介し，「健康危機管理」に自然言語処理が果たしうる貢献について検討する。こ れらの事例に示されるように，災害時には保健医療に関わる膨大なテキストが発生 するものの，保健医療分野の専門家は大量の自由記載文を効率的に処理する手段を 有していない，今後，東日本大震災において生じたデー夕を活用し，保健医療情報 における大量の自由記載文を効率的に処理する備えを行っておくことが望ましい. キーワード: 健康危機管理, 公衆衛生, 自然言語処理

\section{Health Crisis Management and Natural Language Processing}

\author{
TAKashi OKumura $^{\dagger}$ and Yasuhiro Kanatani ${ }^{\dagger \dagger}$
}

Disasters may cause a variety of health problems in the victim population, and public health authorities are forced to assess such situations rapidly in order to take appropriate countermeasures. This process may involve the processing of numerous unstructured texts, and hence, natural language processing (NLP) has significant application potential in the field of crisis response. This report classifies the information related to public health in a crisis situation into three categories - victims, victim groups, and care providers - and summarizes the characteristics of these categories to clarify the tasks suitable for NLP. This analysis is followed by three case studies of the Great East Japan Earthquake response. These case studies illustrate the contribution of NLP in an actual health crisis and suggest that the authorities do not possess appropriate means to process the texts that may accumulate in such a situation. The archive of the earthquake would be the best source for the analysis to prepare for future disasters.

Key Words: health crisis management, public health, natural language processing

\footnotetext{
† 国立保健医療科学院研究情報支援研究センター, Center for Public Health Informatics, National Institute of Public Health

†† 国立保健医療科学院健康危機管理研究部, Department of Health Crisis Management, National Institute of Public Health
} 


\section{1 はじめに}

災害は，住居や道路などに対する物的損害だけでなく，被災地内外の住民に対する健康への 影響も及ぼしうる。そこで, 従来の防災における危機管理の考えを援用し, 健康における危機 管理という概念が発達しつつある。この「健康危機管理」は，わが国の行政において，災害，感 染症, 食品安全, 医療安全, 介護等安全, 生活環境安全, 原因不明の健康危機といった 12 分野 に整理されており，厚生労働省を中心として，それぞれの分野において生じうる健康問題とそ の対応策に関する知見の蓄積が進められている (谷畑，奥村，水島，金谷 2012).

こうした健康危機においては, 適切な意思決定のためにできる限り効率的に事態の全体像を 把握する必要性がある。しかし, 2009 年に生じた新型インフルエンザによるパンデミックでは, 国内の発症者や疑い症例の急激な増加に対し，状況把握に困難が生じていた (奥村 2009)。2011 年に生じた東日本大震災においては, 被災地の行政機能が失われ，通信インフラへの被害も合 わさって, 被災地の基本的な状況把握すら困難な状態が生じた(震災対応セミナー実行委員会 2012). とりわけ，災害初期の混乱期においては，事態の全体像を迅速に把握する必要があり， 情報の厳密性よりも行動に結びつく実用性や迅速性が優先されうる (國井 2012). この「膨大な テキスト情報が発生」し，また，「情報の厳密性よりも迅速性が優先される」という特徵は，自 然言語処理が健康危機管理に大きく貢献しうる可能性を示している.

そこで本稿では，健康危機に打ける情報と自然言語処理との関係について整理し，自然言語 処理が健康危機管理に果たしうる役割について検討する。まず，次章では，健康危機に扔ける 情報とその特徵について整理する．３章では，筆者らが関わった東日本大震災に対する保健医 療分野の情報と自然言語処理との関わりをまとめ, 4 章において提言を記す.

\section{2 健康危機管理における情報とその特徵}

震災やパンデミックにより引き起こされる健康危機時においては, 被災者に関する医学的情 報や医療機関の損害情報, 支援物資に関する情報など, 様々な情報が生じることになる。実際, 東日本大震災の後には，災害支援における情報の処理に様々な課題が生じ，その効率化に向け て多くの情報システムが開発された (Utani, Mizumoto, and Okumura 2011)。 以下では, 保健医 療活動の観点から, 情報を対象毎に分類し，その特徵を整理する.

\section{1 被災者に関する情報}

まず，個々の被災者に関する健康情報が挙げられる，災害による怪我などの急性疾患に関す る情報の他，持病や内服薬に関する情報，栄養状態に関する情報は，適切な医学的管理に欠か せない，一方で，緊急時においては，利用できる検査や医薬品にも限りがあり，また，患者の 
診療記録についても，通常時とは異なった簡潔さが求められることになる，患者の状態を緊急 度により分類する「トリアージタグ」は，患者情報を極限まで簡素化したもので，言語表現が 関与する余地は夕グに含まれる特記事項欄の記載に限られている。これは極端な例ではあるが, 災害時においては，災害用カルテの利用など多かれ少なかれ診療記録にも大幅な省力化が図ら れる傾向がある.

こうした患者情報は，電子化されているケースもあれば，混乱する被災地の医療現場で必要 最小限の記録を残すために紙に記載されているケース，さらには，紙への記載すら困難な状況 下で患部に巻いた包帯の上に最小限の処置内容と指示のみを記載する例などもあり，すべてが 自然言語処理の対象として適した形態とは言えない.しかしながら，こうした個々の被災者に 関する医学情報は，適切に処理することにより様々な活用が可能である。まず，i）多数の患者 情報の中から, 特別な治療が必要なケースなど, 条件に見合った患者を抽出する活用が考えら れる。ただし，緊急性の高い患者については，直接診察にあたる医師により対応が行われるは ずであり，また，直接診察以上の情報をカルテ解析より見出すことには本質的な困難さがある. 次に, ii) 多数の患者情報の中から, 症状や疾患に関する一定の傾向を読み取り, 支援や対策に 生かすという目的が考えられる。たとえば，感染症の集団発生や呼吸器疾患の上昇などが把握 できれば，必要な予防を講じることが出来る。カルテ解析は，医師による労働集約的な作業が 求められるために非常時に行うには困難が伴うが，自然言語処理により改善がもたらされる可 能性がある，最後に，iii）歯科カルテ等を用いることで，ご遺体等の個人同定が行われるケース がある。ただし, 遺体側の特徵として, 歯科治療跡が保存性, 視認性共に優れることから, こ のケースにおいて自然言語処理が関与しうる余地は未知数である.

\section{2 被災者集団に関する情報}

被災者の状況の詳細な把握に際しては，上述のように個人毎の情報管理が求められる。しか しながら, 発災初期など, 数百人が収容された避難所から個々人の医学情報を正確に収集, 管 理することは容易ではない. そこで, とりわけ発災直後の混乱期において，避難所毎の大まか な人数や電気, ガス, 水道, 食料等, 集団に関する情報の収集と共有が優先されることになる. 保健医療の観点からは, これらに加えて, 特別な配慮が求められる妊婦の数や, 乳児や高齢者な どの災害弱者数, 衛生状態, 食事の加熱の有無等が求められる。さらに, 支援に際しては, 定 量的な情報だけでなく, 被災地域のニーズや避難所で行われている工夫等が文字情報として収 集されうる。

こうした現地報告からは，様々な情報の抽出と分析が可能である。その中でも，保健医療系 の domain expert が抽出したいとした情報は, 後述する被災地支援活動を行った栄養士の現地 報告会 (須藤 2012) での意見を分析すると，主に 4 種類に分類されたままず，i）要所を押さえ た記録の「要約」が挙げられた。とりわけ，保健医療分野では多くの支援が交代制により行わ 
るため, 後発チームが支援先においてなされている活動の概要や目下の課題を効率良く知りた いというニーズが少なくない. したがって, 先発チームの報告を効率的に要約する技術により, 報告する先発チーム, 報告を受ける後発チームの双方の負担を軽減できる可能性がある。また, ii）報告文書には, ベストプラクティスや避けるべき行動などの現場で見出された様々な知見が 含まれる。報告文書の解析に際しては，こうした情報を適切にまとめることで，今後の活動ガ イドラインの反映に繋げたいという要望も挙げられた，災害時のさまざまな記録から作成され たガイドラインとしては，たとえば，阪神淡路大震災後に編纂された資料が参考となるだろう (内閣府 1999)，さらに，iii）災害やその支援において生じた事態と対応を整理し記録する「適 切な整理と保存」へのニーズも認められた。 この震災対応のアーカイブ化については, 国立国 会図書館 (国立国会図書館 2012) や東北大学 (東北大学災害科学国際研究所 2012) を初めとした 多くの試みがあるが，保健医療系では体系的な取り組みがなされておらず，情報系研究者によ る支援が望まれている。最後に，iv）過去の報告内容を分析することで，状況把握の適切化・迅 速化・省力化に向けた「報告書式の改善」に繋げたいという要望が存在した．現地状況をより 詳細に把握するために報告が詳細化すると，報告者の負担が増してしまう。しかし，苦労をし て報告した情報も，被災地の状況や今後の災害対応に生かされなければ，報告者の士気を保つ ことが困難である。そこで，報告書式や手法そのものを過去の経験に基づき改善して欲しいと いう要望が生じることになる。これら四種の希望は，栄養士に限らず，広く保健医療系の支援 活動に当てはまる一般性を有すると考えられる.

\section{3 支援者に関する情報}

次に，支援者側の情報が挙げられる。災害時の保健医療情報としては，被災者や避難所の情 報に注目が集まるが，医療支援は，医師や歯科医師，看護師，保健師，薬剂師等，他職種の連 携により初めて機能する。したがって，適切な医療支援を行うためには，支援者側の情報を効 率的に収集すると共に, 被災地ニーズと支援者とのマッチングを最適化していかなければなら ない. また，行政における支援には厳密な労務管理が求められるために，活動報告を適切に収 集，管理することは行政上の要請でもある.

こうした情報は, 派遣前に収集される属性情報と, 派遣してから継続的に収集される活動情 報に分類される。前者は, 派遣チームの編成, 派遣先, スケジュール等のマッチングに役立て るもので, 言語表現が関与する余地が少ない。一方，後者は，支援者の専門性に基づく現地の 課題や対応等が収集しうる可能性がある他, 支援にまつわる各種の意思決定を評価, 改善して いくための基礎資料となりうる。実際, 東日本大震災においては, 日々届けられる派遣行政官 の日報を人事部門が目視確認し，支援の改善に繋げていた自治体があったという。また，支援 者は, 多くの遺体や苦境に喘ぐ避難民に接することでストレスが生じがちであり, 報告書を通 じて支援者側のメンタルヘルスを適切に管理する仕組みも検討の余地がある. 


\section{4 まとめ}

このように，健康危機管理においては被災者や支援者に関する情報が欠かせない。上述の例 では，被災者情報のフィルタリング，情報抽出，個人同定，被災者集団情報からの文書要約，情 報抽出，文書分類ないし情報検索技術，支援者情報からの情報抽出等が求められていることを 示した。また，支援活動の最適化にとっては，上記以外にも，被害を受けていない都道府県に おける透析施設や老人保健施設の情報など被災地以外の情報も欠かせない. 被災地以外からの 情報は，定量的情報が多いが，たとえば，パンデミック対応においては，海外から刻々ともた らされる感染情報や治療効果に関する最新情報の整理など，自然言語処理が貢献しうる余地は 少なくない。 これらは, 高い精度よりも効率性が重視される処理であり, 多少の不完全性を許 容しうる点でも，自然言語処理の有望な応用分野であると言える.

一方，健康危機時に発生する情報には，下記の点で，自然言語処理を応用していく上での障 害がある。まず，医療や医学に関する情報は専門性が高いことが一般的であり，些細な情報の 解釈においても医学や栄養学などの domain knowledge が求められる. たとえば, 降圧薬と抗精 神薬が足らないという情報に触れた際, どちらがより重要か, あるいは緊急性が高いか, とい う解釈は，医学知識の有無により大きく異なるだろう。また，医療や公衆衛生に関わる情報に は，公的機関が関与することが多く，収集した情報に個人情報保護の制約が課され自由な解析 や活用が困難となるケースが少なくない，さらに，公的機関には，様々な情報が集まり易い一 方で, 情報系人材が少なく, また，予算上，外部に技術支援や情報解析を依頼することが困難と なりがちであることから，収集された情報が有効活用されないケースが往々にして生じる。こ れらの条件は，健康危機管理における自然言語処理研究を進めるうえで大きな障害となりうる が，東日本大震災を経て，保健医療分野における情報処理の効率化に向けた問題意識は関係者 間で共有されつつあり，次に述べるような試験的な試みが進められている.

\section{3 東日本大震災における健康危機と自然言語処理}

本章では，以上の観点から，東日本大震災において筆者らが関わった保健医療分野の言語処 理について概要を整理する。

\section{1 日本栄養士会 支援活動報告}

東日本大震災においては，東北地方沿岸部を中心に広範囲に渡って甚大な被害が生じたそそ のために，避難所に 1 次避難した被災者のための仮設住宅が行き渡るまでにも時間が掛かり， また， 2 次避難後にも，物流等の問題から被災者が口にしうる食事のほとんどが配給によるも のとなりえた，そこで，栄養の偏りによる健康被害を避けるため，栄養士の職能団体である公 益社団法人日本栄養士会が被災地における栄養管理に取り組んだ。栄養士による災害支援は新 
潟県中越地震 $(2004)$, 能登半島地震 $(2007)$ より開始され, これらの震災においては被災者の個 人単位での栄養指導と記録も試みられていた。一方，東日本大震災においては，支援者単位で の活動報告が行われた。

図 1 に，今回用いられた活動報告書式を示す。震災後，MS Word，PDF，手書きと，複数の 形式で，合計 4103 件の活動支援報告書が収集され，その後，数值や自由記載文が混在した MS Excel 形式へと統合した $(1,524 \mathrm{~KB})$. 下記に，報告書式に含まれる一日の活動内容についての 文例を記す。

$\bigcirc \bigcirc 0$ 病院医師宿舎到着 海外支援物資の缶詰の試食と記録 試作 全体的にスパイシーな味付けが多いが，いわしの油浸けはアレンジの仕方によっては和風 になるので，避難所で実践してもらえれば，と思う．

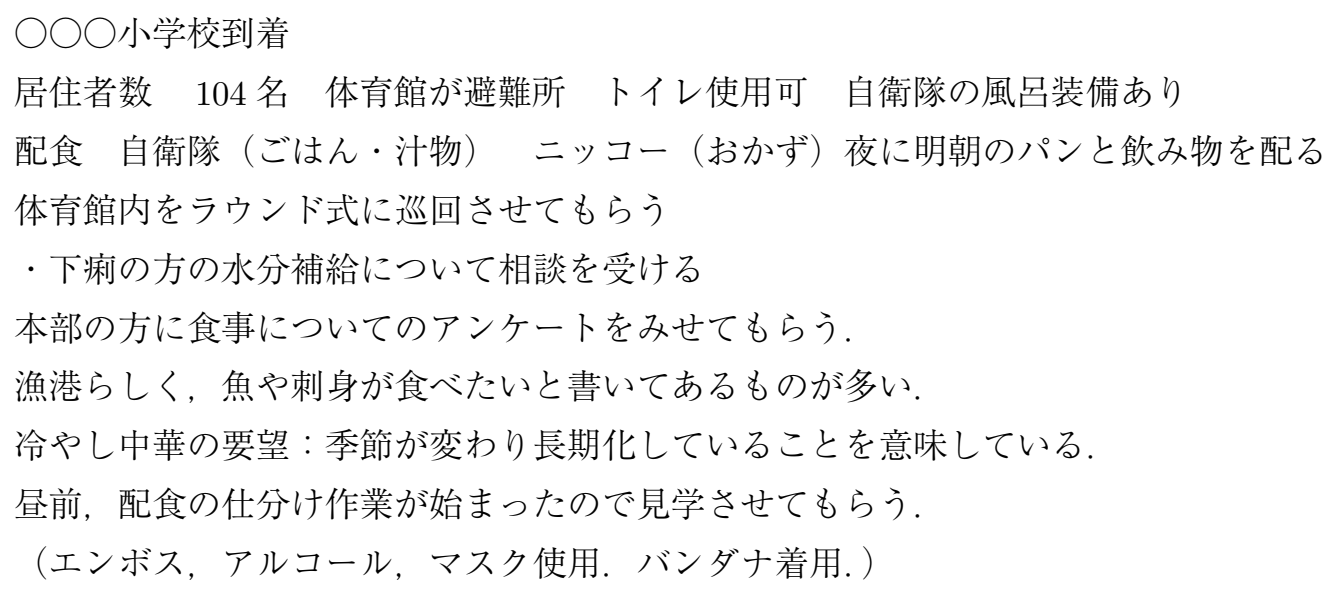

今回は，活動報告書式の構造化が不十分であったため，以上のように，支援対象の避難所の 状況報告と, 具体的な活動内容, その評価が混在した文となっている. 今後, 報告書式を改良 することにより, 現地の避難者数や衛生状態などに関するより効率的な情報集積が可能となる ことが伺われる。一方で,「冷やし中華への要望」というエピソードからは, 支援活動において は, 単なるカロリー量や栄養素などの数量的な問題を解決するだけなく, 調理法やメニューな ど様々なレベルでの問題解決が求められている点, ならびに, 数值情報からは読み取りえない 質的情報を扱う必要が理解されよう。 


\section{災客支援現地活動報告（榬式1）}

\begin{tabular}{|c|c|}
\hline \multicolumn{2}{|c|}{ 記事（今日の行動を時系列に記橶してください）(用組が足りない場合は様式2を使用) } \\
\hline 時 間 & 内 容 \\
\hline \multirow{3}{*}{$\begin{array}{l}\text { 閏迨時间 }(13: 40) \\
13: 40 \sim \\
14: 00 \sim\end{array}$} & \\
\hline & 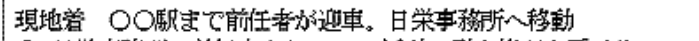 \\
\hline & @ 日慈事務所 前任者より PCAT 活動の引き継ぎを受ける \\
\hline \multirow[t]{2}{*}{$15: 30 \sim$} & 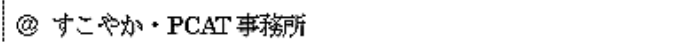 \\
\hline & 現地チームへ登録力ード記入・PCデータのコピー手期の説明 \\
\hline \multirow{2}{*}{$\begin{array}{l}16: 00 \sim \\
17: 00 \sim\end{array}$} & (9) すこや小・PCAT 事雅航 PCATミーティング夌加 \\
\hline & (9すこやか・多目的ホール DMATミーティング茤加 \\
\hline \multicolumn{2}{|c|}{ 支援物資の利用（被災者にこ対する支援物資等を使用した場合に記鍕してください) } \\
\hline \multicolumn{2}{|c|}{ なL } \\
\hline \multicolumn{2}{|l|}{ 同行者 } \\
\hline \multicolumn{2}{|l|}{ なし } \\
\hline \multicolumn{2}{|c|}{ 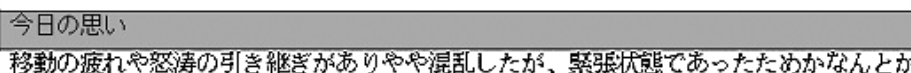 } \\
\hline \multicolumn{2}{|c|}{ 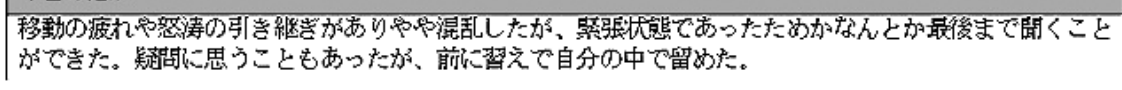 } \\
\hline
\end{tabular}

図 1 支援活動報告書式

次に，報告書式中の「今日の思い」と題された一日の感想欄に記載された文例を記す.

「元の生活に戻していく」ことを目標に医療支援が縮小・撤退していく中で，過剩診療に ならないように支援することの難しさを痛感した。栄養剤の配布についてもいつまでも支 援できるわけではないので，今後は購入してもらうかもしくは市販食品での代替を念頭に 入れて栄養ケアプランを考える必要性がある。また，患者を見ている家族も被贸者である ことから，患者の栄養状態だけを見るのではなく，周りの状況をよく理解した上で食事相 談をしなくてはならないと思った。

災害支援においては，まず被災地全体のアセスメントを行い，必要物資の量的なマッチング を行う。しかしながら，人間的な生活を回復していく過程においては，事前に想定された調査 項目に基づく量的情報の集積だけではなく, 現地の様々な状況に関する質的情報が欠かせない. 上述の例では，栄養剤を配布することにより数值の上では現地ニーズを満たしても，適切な撤 退戦略を立案するためには地域毎の特性や復興計画, 進渉状況を考慮することが不可欠である ことが読み取れる。そのためには，オペレーションズリサーチのような最適化技術だけではな く, 現地に関する膨大な自由記載文から状況や課題, 解決提案等を効率的に抽出する技術が不 可欠であり，自然言語処理が災害支援に大きく貢献しうる可能性が示唆される. 
そこで，筆者らのグループでは，今回の支援活動報告を活用した自然言語処理研究を支援し て来た (岡崎, 鍋島, 乾 2012; 荒牧 2012; 風間 2012). また, 上述のように, 避難所の状況, 活 動内容, その評価等が混在した文章からの情報抽出は効率が悪いために，より効率的な解析に 向けて, 支援活動報告における数值等の構造化された情報と自由記載文のベストミックスにつ いての考察を試みた (奥村, 金谷 2012). さらに, 報告の自由記載欄に支援者自身の急性ストレ スの兆候が認められたことから，支援者の活動報告の解析によるストレス症状と早期発見によ る PTSD (Posttraumatic stress disorder) 対策について, 検討を行っている.

\section{2 石巻圏合同救護チーム 災害時用カルテ}

災害時の医療支援においては，メンバーが入れ替わる医療チームにより医療が供給されるこ とになるため，かかりつけ医などが継続して治療に当たる平常時以上に診療記録の重要性が高 まる、また，通院中の医療機関におけるカルテを継続利用することが困難なために，医療支援 にあたる団体等が災害時用カルテ（災害時救護記録）を用いるケースもある。

今回の東日本大震災において, 石巻圈では広範な範囲に渡り医療機関が深刻な被害を受けた。 そこで，全国より日本赤十字や医師会など様々な組織が医療支援に訪れたが，それぞれの医療 チームは短期滞在であったため, どのチームがどの地域で何をするのかの調整が求められた。 ま た，数多くの避難所から統一的な情報収集体制を構築する必要に迫られた。そこで，石巻圈合同 救護チームは, 広範な医療圈を 15 のエリアに分割し, エリア内の情報集約や短期滞在する医療 チーム間での引き継ぎをエリアの責任者に託す分割統治戦略を取った，その際，石巻圈合同救 護チームの本部がある石巻赤十字病院が主導し, 災害時用カルテの運用を行った (田中 2012).

図 2 に, 今回用いられたカルテの書式を示す。震災後, 合計 25,387 枚のカルテが収集され, 現在, 全カルテが PDF 化されている (3.19 GB). このうち, とりわけ患者の多いエリア 6,7 の 9,209 人分のカルテについて, 氏名, 年齢, 性別, 既往歴, 診断, 処方等の情報を目視で抽 出し, 本災害カルテに即して設計したデータベースに入力し， 1 診療を 1 レコードとしてデー 夕化を行った結果, 合計 23,645 件のデータ化が完了している. 図 2 に示されるように, カルテ においては略称や特殊な表現が多く, 医学知識がなければ記載されている情報を読み取ること ができない，そのために，データ入力が高コストとなりがちであり，収集した全力ルテをデー 夕化することができていない. また，データ化においては，カルテに記載された現病歴（疾患 の発症から受診に至る経緯が文章で記載されたもの）等のテキストが割愛されている。そのた めに，今回収集されたカルテの本格的な解析においては，データベースをインデックスとして 使用し，条件に当てはまる患者を抽出した上で，必要な情報抽出を再びPDFから行う必要があ る。たとえば，本データベースを利用してとある薬剤が処方された患者を抽出することは可能 であるが，その処方が震災前より内服していた薬を在庫のある薬に切り替えた結果であるのか, 震災により新たに生じた症状に対して処方した結果であるのかを知るためには, 専門家がPDF 


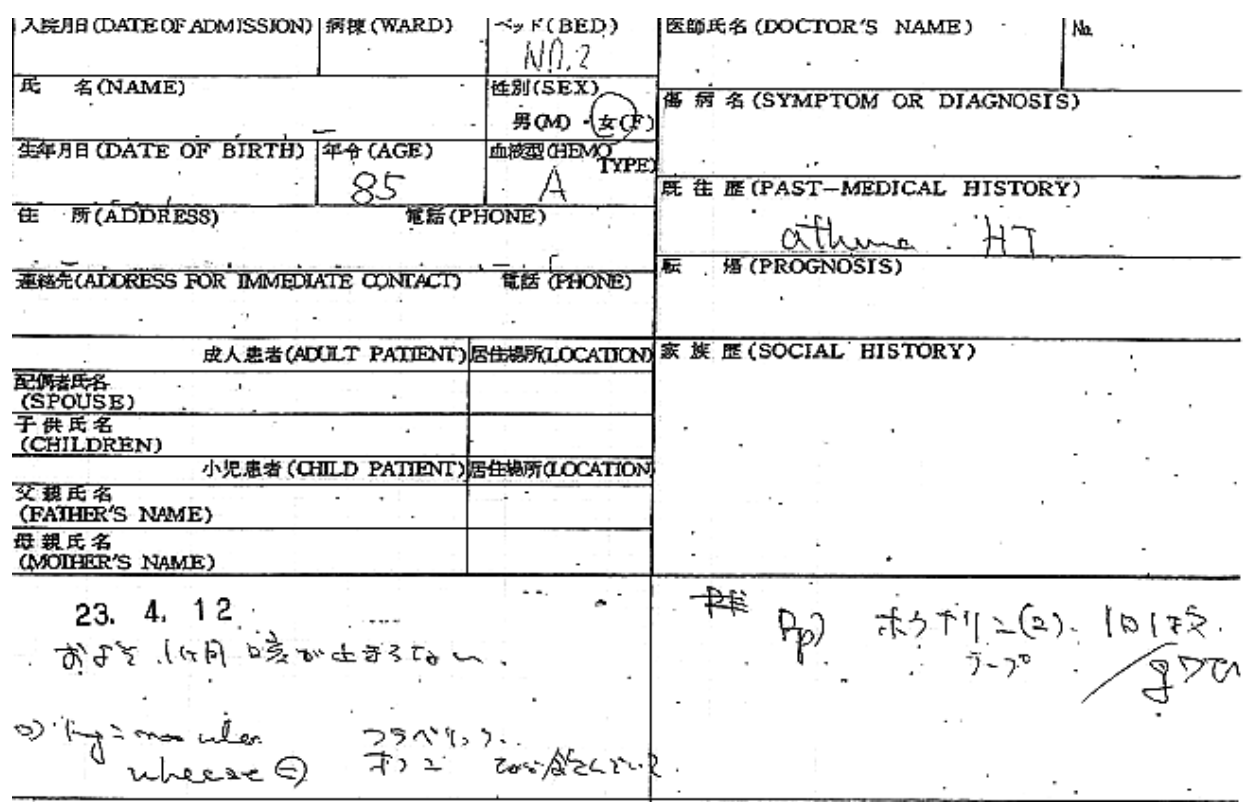

図 2 災害カルテの例

を目視確認する必要がある。

災害時に集積されるカルテは，災害による健康への影響に関する貴重な一次情報である。そ のために, 迅速な分析により, 地域に生じた新たな感染症や慢性疾患の増悪等の情報が得られ, 効果的な被災地支援に繋がりうる。また，事後解析により将来の災害にも役立ちうることにな る。一方で, カルテの解析には専門知識が不可欠であり, プライバシーの問題も生じることか ら，効果的な解析手段が無ければ，折角の情報が死蔵されてしまう懸念がある。とりわけ，「災 害により引き起こされたと考えられる病態に関する情報の抽出」は, 既存のカルテ解析とは異 なる課題であるため，今後，災害カルテのデジタル化と効率的な解析に向けた自然言語処理技 術の発展が望まれる。

\section{3 医療・公衆衛生系メーリングリスト情報}

被災地では，震災後から，行政が主導するDMAT（災害派遣医療チーム：Disaster Medical Assistance Team)，日本医師会による JMAT (Japan Medical Assosiation Team) や日本赤十字 社，日本プライマリケア医学会による PCAT 等の医療支援チームが数多く活動した。また，保 健所等において公衆衛生に携わる公衆衛生医師や保健師等の派遣や, 東日本大震災リハビリテー ション支援関連 10 団体など，職能団体による支援も数多くなされた。 これらの活動により被災 地入りした医療従事者は, 震災直後より, 学会や各種団体, 同空会等の組織が維持するメーリン グリストに多くの現地報告を投稿した。一例として，筆者の所属するメーリングリストに 2011 
年 3 月 14 日に投稿された現地報告の抜粋を以下に示す.

同日朝より○○地区の災害現場の担当となり，要救護者の対応や死亡確認などを行いまし た，津波による影響で民家はすべて崩壊していましたが，歩行困難患者と低体温患者を数 名処置し病院に搬送しました。ただし，その午後および翌日は死亡者の確認がほとんどと いう残念な状況でした，消防および救急隊，自衛隊と一緒になって活動しましたが足場も 悪いため死亡者も見た目で分かるところ以外の検索は困難であり，時折来る津波警報で撤 退し，落ち着いたら再び現場に戻るを繰り返していました。死亡者も多くその場から回収 できない状態です。DMATとして現場ではあまり役に立てず，本当に心が痛みました。

例文に示されているように，本報告には，i）現地の客観的な情報（津波の影響で民家はすべ て崩壊), ii) 具体的な活動内容 (軽症例の処置と死亡確認), iii) 活動の医学的な評価 (DMAT は現場で役に立たなかった），iv）報告者の主観的な感想（心が痛んだ）が混在している。しか しながら, 高度に訓練を積んだ医療従事者による現地報告には, 要所を押さえた現地情報や活 動の評価等の貴重な情報が，発災後の早い段階から含まれていたことが分かる．

災害時における被災情報をソーシャルネットワークから抽出する試みにおいては，発信者の 匿名性や伝聞情報による擋乱が課題となる。一方で，医療従事者によるメーリングリストは，報 告者の特定が容易であり, 情報源としての確度が高い. また, 情報の専門性も高く, 投稿数も豊 富であった。そのために，災害の支援活動初期に生じる膨大なテキストからこれらの情報を効 率的に抽出する技術は，その後の災害支援活動にとって極めて有益となる可能性がある。一方 でメーリングリストへの投稿文は構造を持たないことに加えて，人命に関わる意思決定に関 係することから情報抽出の精度が求められ, 自然言語処理には適さない課題かも知れない. し かしながら，自然言語処理を活用した各種ツールが大量の情報整理を効率化する可能性は依然 として高く，首都圈における大規模災害時等，多量の情報が発生することが想定される災害へ の備えとして，求められる自然言語処理技術のあり方を検討しておくことが望ましい.

\section{4 おわりに}

わが国は, 地震や風水害が多いだけでなく，狭い国土に多くの国民が住むことから，高度成 長期に多発した環境污染問題など，大規模な健康問題が生じるリスクを常に抱えている。とり わけ，首都圈直下型地震のような大災害やパンデミックは常に発生する可能性があり，これら の際には保健医療に関わる膨大なテキストが発生しうる。そこで, 厚生労働省も, 健康危機へ 
の備えとして, 既知の経験を収集し (谷畑 他 2012), 避難者情報の効率的な把握と共有に向けた 研究投資を行ってきた (水島，金谷，藤井 2012).

しかしながら, 情報の柔軟性を担保するうえで必要となる自由記載文に対しては, 依然, 効率 的な処理手段を欠いている。具体的には, 被災者情報のフィルタリング, 情報抽出, 個人同定, 被災者集団情報からの文書要約，情報抽出，文書分類ないし情報検索技術，支援報告からの情 報抽出等は，ほとんど手付かずの状況にある。一方，これらはまさに自然言語処理が取り組ん できた課題であり，東日本大震災の教訓を生かすうえでも，今回の災害が遺した教訓とデータ を元に保健医療情報における大量の自由記載文を効率的に処理する備えを行っておくことが望 ましい. 筆者らも, 可能な限りでの情報の保存と研究利用に向けた環境整備に努めており, 今 後, 自然言語処理研究者による集積したデータの活用と研究分野としての発展を願っている.

\section{謝 辞}

本稿の背景となった，東日本大震棪における保健医療分野の対応を自然言語処理を用いてご 支援頂く試みにおいては，グーグル株式会社 賀沢秀人氏に多大なご尽力を賜った。また，奈 良先端大 松本裕治先生, 東北大学 乾健太郎先生, 情報通信研究機構 鳥澤健太郎先生, 東 北大学 岡崎直観先生, 東京工業大学 橋本泰一先生, 東京大学 荒牧英治先生, 富士通研究 所 落谷亮氏の各先生方からは, 多くの御助言を頂き, また, 実際の解析の労をお取り頂いた. お茶の水女子大学 須藤紀子先生, 国立健康 - 栄養研究所 笠岡（坪山）宜代先生, 日本栄養 士会 下浦佳之理事，清水詳子様には，災害時の栄養管理に関する自然言語処理に関して御指 導を賜った。また，査読者の方々には，有益なご助言を多数頂いた。この場をお借りし深謝申 し上げます。

\section{参考文献}

荒牧英治 (2012). 言語処理による分析一支援物資の分析. 日本栄養士会雑誌, p. 8.

風間淳一 (2012). 言語処理による分析一活動報告の評価情報分析. 日本栄養士会雑誌, p. 9 .

国立国会図書館 (2012). 東日本大震災アーカイブ. http://kn.ndl.go.jp/.

國井修（編）(2012). 災害時の公衆衛生一私たちにできること．南山堂.

水島洋, 金谷泰宏, 藤井仁 (2012). モバイル端末とクラウド, CRM を活用した災害時健康支援

システムの構築. モバイルヘルスシンポジウム 2012.

内閣府 (1999). 阪神・淡路大震災教訓情報資料集.

http://www.bousai.go.jp/kyoiku/kyokun/hanshin_awaji/data/.

岡崎直観，鍋島啓太，乾健太郎 (2012). 言語処理による分析一日本栄養士会活動報告の分析. 日 
本栄養士会雑誌, pp. 6-8.

奥村貴史 (2009). 新型インフルエンザ対策を契機とした国立保健医療科学院における反復型開

発による感染症サーベイランスシステムの構築. 保健医療科学, 58 (3), pp. 260-264.

奥村貴史，金谷泰宏 (2012). 災害時における支援活動報告. 日本栄養士会雑誌, pp. 12-13.

震災対応セミナー実行委員会 (2012). 3.11 大震災の記録一中央省庁・被災自治体・各士業等の

対応. 民事法研究会.

須藤紀子 (2012). 東日本大震災における被災地以外の行政栄養士による食生活支援の報告会. 厚

生労働科学研究費補助金 健康安全・危機管理対策総合研究事業『地域健康安全を推進するた

めの人材養成・確保のあり方に関する研究』平成 23 年度総括・分担研究報告書, pp. 126-152.

田中博 (2012). 災害時と震災後の医療 IT 体制：そのグランドデザイン。情報管理, 54 (12), pp. $825-835$.

谷畑健生，奥村貴史，水島洋，金谷泰宏 (2012). 健康危機発生時に向けた保健医療情報基盤の

構築と活用. 保健医療科学, 61 (4), pp. 344-347.

東北大学災害科学国際研究所 (2012). みちのく震録伝. http://shinrokuden.irides.tohoku. ac.jp/.

Utani, A., Mizumoto, T., and Okumura, T. (2011). "How Geeks Responded to a Catastrophic Disaster of a High-tech Country: Rapid Development of Counter-disaster Systems for the Great East Japan Earthquake of March 2011." In Proceedings of Special Workshop on Internet and Disasters (SWID 11).

\section{略歴}

奥村 貴史：1998 年慶應義塾大学大学院修了. 2007 年国立旭川医科大学医学部 医学科卒業, 同年ピッツバーグ大学大学院計算機科学科にて Ph.D. (Computer Science). 2009 年国立保健医療科学院研究情報センター情報評価室長, 2011 年より研究情報支援研究センター特命上席主任研究官.

金谷 泰宏 : 1988 年防衛医科大学校卒業, 医学博士, 1999 年厚生省保健医療局 エイズ疾病対策課課長補佐, 2003 年防衛医科大学校防衛医学研究センター准 教授, 2009 年国立保健医療科学院政策科学部長, 2011 年より同院健康危機管 理研究部長. 